\title{
CD-Based Interactive Multimedia on Integrative Thematic Learning in Elementary School
}

\author{
Reza Rachmadtulla ${ }^{1}$, Vina Iasha $^{2}$, Rasmitadila $^{3}$, Harlinda Sofyan $^{4}$ \\ \{rezarachmadtullaheza@gmail.com ${ }^{1}$ \} \\ Universitas Negeri Jakarta, Indonesia ${ }^{1,2}$ \\ Universitas Djuanda, Indonesia ${ }^{3}$ \\ Universitas Esa Unggul, Indonesia ${ }^{4}$
}

\begin{abstract}
The purpose of this study was to develop CD-Based Learning Multimedia in Integrative Thematic Learning in Elementary School. The method used in this study was research and development, CD-Based Interactive Multimedia which was then validated by thematic concept experts and media experts, the results of this study showed that the multimedia developed has a valid and significant assessment so that multimedia is one of the learning media that can be used to deliver material to students very effectively and efficiently.
\end{abstract}

Keywords: Integrative Multimedia, Integrative Thematics, elementary school

\section{Introduction}

The rapid progress of information technology provides convenience to us in packaging and presenting information in various forms and media, both conventionally (books, leaflets, newspapers, magazines, tabloids, and posters), or in electronic or digital formats (eg internet, movies / DVD / VCD, audio cd, interactive cd, map and digital image) [1]. The availability of a large selection of presentation media, the data or material that we have can be presented more interesting, tasty and easy to read and contain elements of entertainment [2], [3].

In learning activities in elementary schools, the use of tools in the form of learning media can make abstract things more concrete and make the learning environment unattractive interesting especially integrative thematic learning in elementary schools [4]. Many learning tools or media are created for independent learning nowadays, but to find a truly good choice or solution for the learning process to be effective, interesting and interactive, as well as fun, is a problem that needs a solution [5].

Tools or media for independent learning in an era of technological advancement are needed in an integrative thematic learning process in elementary schools[6], [7]. Learning media have many types and are not one of the best media compared to other media. Each media has its own advantages and disadvantages [8]. Therefore teachers need to know various media with their respective characteristics [9], [10]. Thus the teacher can choose and use it in accordance with basic competencies, student characteristics, material to be delivered and learning experience [11].

According to Arsyad [12] said that: Media, when understood broadly, is human, material, or event that builds conditions that make students able to obtain knowledge, skills or attitudes. In this sense, the teacher, the textbook, and the school environment are the media. In 
particular, the media in the teaching and learning process tends to be interpreted as graphical, photographic or electronic tools to capture, process, and reconstruct visual or verbal information. Therefore, the selection of learning media by teachers is very important [13], [14] . There are many learning media that can be used, one of which is CD-based Interactive Multimedia. CD-based interactive multimedia is a media that can be packaged in a CD (Compact Disk) whose purpose is interactive applications in it and also has several menus that can be clicked to display certain information. The advantages of CD-based multimedia integrative are users can interact with computer programs, increase knowledge. The knowledge in question is the subject matter presented by the Interactive CD. An attractive audio-visual display [15], [16].

Learning using CD-based integrative multimedia provides information that can contain data, manuscripts, photos, films / VCD, digital maps, programs and games that are packaged in one $\mathrm{CD}$. Through this $\mathrm{CD}$, users can interact directly and choose what information they want [17]. A number of menus are presented to make it easier for users to choose the topic and type of information provided. Interactive CDs can be used to present various information, for example, folklore, how to make something or how to process products, an introduction of research results, and technological packages (eg how to cultivate an agricultural commodity) [18].

The results of the study conducted by Wulandari et al, [19] showed that CD-based interactive multimedia was developed properly based on the results of validation conducted by experts and effectively used in learning because it can increase the value of student learning outcomes. Learning using CD-based interactive multimedia is very important because it can convey messages of learning material that can stimulate thinking, and encourage learning to be easy and interesting [20].

According to Vaughan[21] CD-based multimedia integration that is developed with abstract material can be presented with easy-to-understand language, supporting images and animations and attractive displays can increase students' motivation to read content contained in CD-based interactive multimedia. Based on the results of research conducted on CD-based integrated multimedia, we also need to create a CD-based multimedia integrative application on integrative thematic learning in elementary schools. The CD-based multimedia integrative application that we have developed is different from the existing application because the application that we have developed has elements of localization values in the locations we conduct research [22].

Based on the results of problem identification and relevant theoretical studies. So this study aims to create CD-based interactive multimedia applications on integrative thematic learning in fifth-grade students in elementary schools. CD-based interactive multimedia applications developed will be tested for validity by media experts and integrative thematic learning material experts. CD-based interactive multimedia that was developed is expected to be a learning media solution that can be used in learning in elementary schools.

\section{Method}

This study aims to develop CD-Based Learning Multimedia in Integrative Thematic Learning in Primary Schools, the method used in this study is Research and Development. Development research includes the process of finding newness and excellence in the framework of effectiveness, efficiency, and productivity. The research procedure used, namely 
using the Rowntree model research procedure which has three stages, namely: planning, development, and product evaluation. The evaluation used is Tessmer's formative evaluation (Tessmer, 1993)[23]. The stages covered in formative evaluation activities, namely multimedia interactive based on the scientific approach, were subsequently validated by thematic experts and multimedia experts, after being validated and getting input and information from experts who stated that multimedia was feasible to use, multimedia was tested on 100 respondents from 5th grade elementary school in the district under West Kalimantan-Indonesia Province.

The instrument used in this study is to modify the multimedia assessment instrument developed by simatupang [24] the instrument of this study in the form of a questionnaire divided into three parts. The first questionnaire is aimed at integrating thematic material experts who will provide an assessment based on Material accuracy aspects, Content compliance, Complete presentation of material, Suitability of practice questions with indicators. The second questionnaire is aimed at multimedia experts who will provide an assessment based on aspects of Display Design, Navigation, Animation, Text, Typography, ease of use of multimedia. The third questionnaire is aimed at students as users of CD-based interactive multimedia applications. After learning activities using CD-based multimedia applications students are asked to fill out a questionnaire that provides an assessment of the Ease aspects of interactive multimedia, Clarity of instructions for use, Clarity of writing, symbols and Images, Interest in using instructional materials in the form of interactive multimedia[25].

The data analysis in this study is using qualitative descriptive analysis techniques which describe the results of product development in the form of multimedia learning with operational steps in developing CD-based interactive multimedia and testing the level of product feasibility to be implemented on integrative thematic subjects in elementary schools. Data obtained through assessment instruments at the time of the trial were analyzed using descriptive statistics. In this way, it is expected to facilitate understanding of the data for the next process. The results of data analysis are used as a basis for revising the developed media products. Data regarding the responses of students collected through questionnaires were analyzed by descriptive statistics. The results of the questionnaire were analyzed by criteria namely: 4.00-3.50 Criteria Very Good, 3.49-3.00 Criteria Good, 2.99-2.50 Criteria Poor. And 2.49-0.00 criteria are not good. The research data set can be accessed in osf.io Open Science Framework.

\section{Results}

CD-based interactive multimedia developed using Adobe Flash Cs 5 software is one of the interactive multimedia-based media. Using an Interactive CD can integrate media in the learning process, such as a combination of text, images, sounds, videos, animations into a single unit so that users can navigate, interact, create and communicate. After CD-based interactive multimedia was developed, followed by validation by one expert on integrative thematic learning material in elementary school and one instructional media expert. Validation is done to obtain suggestions and assessments based on the aspects that have been determined regarding the feasibility and effectiveness of CD-based interactive multimedia. The results of the evaluation of validation by experts can be seen in the graph below. 


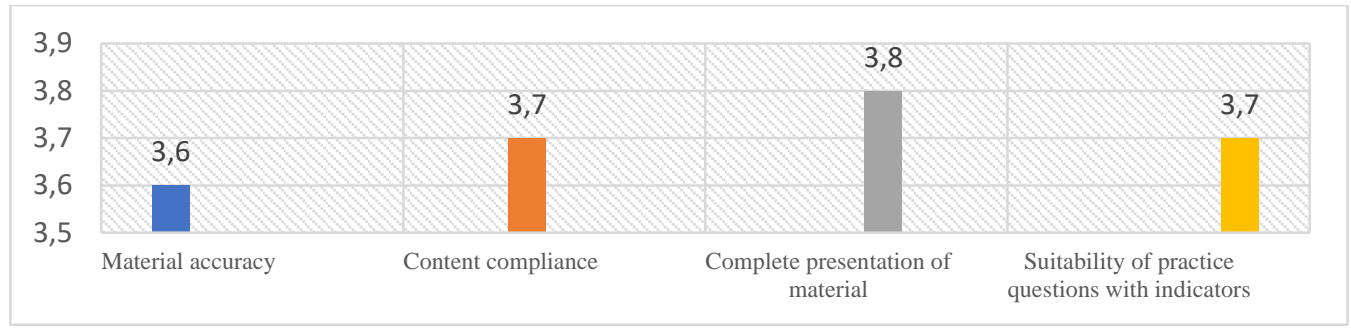

Fig .1. Results of expert assessment of integrative thematic learning material

The results of the assessment by the thematic expert of integrative material accuracy aspects have a value of 3.6 with very good criteria, in the aspect of Content compliance the value of 3.7 is obtained with very good criteria, the Complete presentation of material aspects obtained a value of 3.8 with very good criteria and then on aspects of the suitability of practice questions with indicators obtained a value of 3.7 with very good criteria. Based on the results of the evaluation of the four aspects of integrated thematic learning material on CD-based multimedia integrative development, it can be concluded that the material aspects are feasible to use. Furthermore, the results of media expert validation can be seen from the graph below.

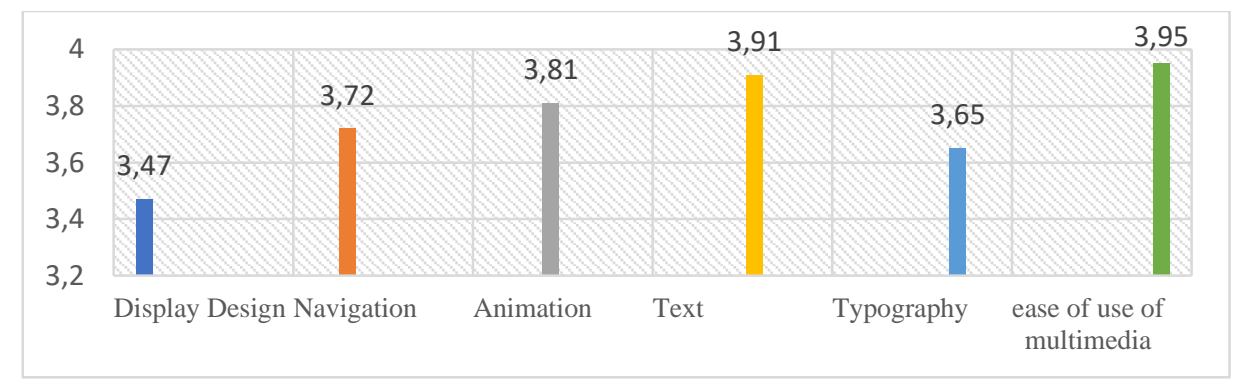

Fig.2. Results of evaluation of learning media expert validation

Based on the results of an assessment by expert learning media on the aspects of Display Design obtained 3.47 with good criteria. The assessment of aspect navigation was obtained 3.72 with very good criteria. The assessment on the Animation aspect was obtained 3.81 with very good criteria. Assessment of the Text aspect is obtained at 3.91. assessment on the aspect of Typography was obtained 3.65 and the assessment of aspects of ease of use of multimedia was obtained 3.95 with very good criteria. Based on the results of the assessment of the six aspects of CD-based interactive multimedia carried out by learning media experts, it can be concluded that CD-based interactive multimedia is feasible. Next is CD-based interactive multimedia in integrative thematic learning in elementary schools that have been valued by learning material experts and media experts. This CD-based interactive multimedia application was tested on 100 elementary school students in the fifth grade with the aim of knowing students' responses to learning activities using CD-based interactive multimedia. The results of student responses that are known through questionnaires obtained that the five aspects of assessment get values above 3.00 means that CD-based interactive multimedia applications are feasible to use and students feel happy learning to use CD-based interactive multimedia applications. The summary of student assessment results on the use of CD-based inactive multimedia applications can be seen in the following graph image. 


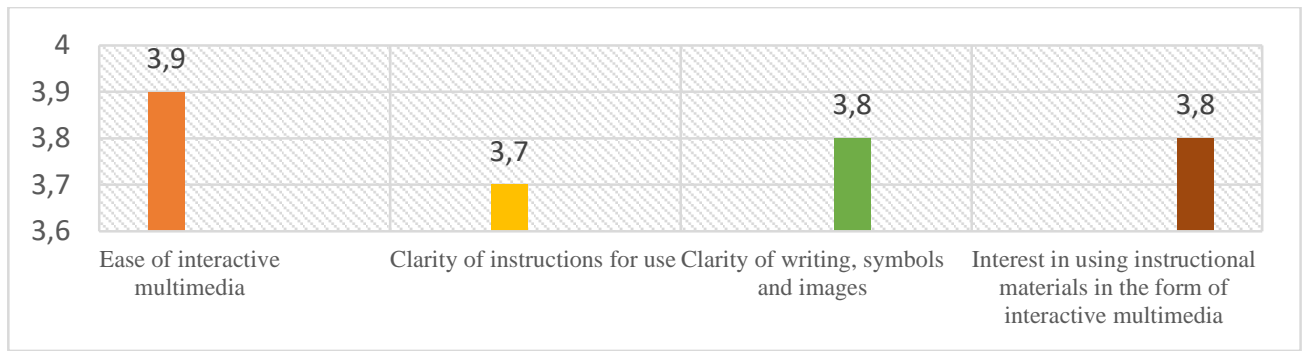

Fig.3.The results of student assessment of CD-based interactive multimedia applications

\section{Discussion}

Based on the results of the study, it is known that the development of CD-based interactive multimedia in integrative thematic learning in fifth-grade elementary school students has proven to be worthy of use. This is because CD-based interactive multimedia applications that are developed have an attractive design appearance and CD-based interactive multimedia applications can clarify the presentation of messages so that they are not verbalism, both in written and oral words and learning using CD-based interactive multimedia applications between students with the latest technology and provide opportunities for teachers to change the rules of teaching and make the learning and teaching process more enjoyable, facilitate learning that focuses on students because students are given the freedom to choose their own learning materials and learn at levels that suit themselves and Multimedia teach each student with a different learning style[26], [27]

\section{Conclusion}

Based on the stages of the results of this study, the conclusions in this study are CD-based interactive multimedia applications in Integrative Thematic learning in elementary schools that obtain appropriate and efficient results after going through the stages of validation testing by thematic learning experts, multimedia experts, and results of student studies. The development of CD-based interactive multimedia applications has a positive impact on solving problems and facilitating the learning process in elementary schools. Because the development of this CD-based interactive multimedia application incorporating text, graphics, audio, video, and animation makes its own attraction in the world of multimedia. For example multimedia in the world of education, a teacher or teacher can easily explain and students can easily understand the concepts that want to be delivered by the teacher. 


\section{References}

[1] I. Y. Rahmawati, "CD Interaktif Sebagai Media Pembelajaran Berbahasa Bagi Anak Usia Dini Di Ponorogo,” J. INDRIA (Jurnal Ilm. Pendidik. Prasekolah dan Sekol. Awal), vol. 1, no. 1, pp. 9-21, Aug. 2016.

[2] J. Chavez, C. Jaramillo, and D. Liberona, "Informational Technology Skills and Media Literacy in Students: A Case Study," 2016, pp. 25-38.

[3] Akrim, "Media Learning in Digital Era," in Advances in Social Science, Education and Humanities Research, 2018, vol. 231, no. Amca, pp. 458-460.

[4] D. Voogt, J., Knezek, G., Christensen, R., Lai, K.W., Pratt, K., Albion, P., Tondeur, J., Webb, M., Ifenthaler, D., Gibson, D.G., Resta, P., Laferrière, T. \& Slykhuis, "International Handbook of Information Technology in Primary and Secondary Education," in Proceedings of Society for Information Technology \& Teacher Education International Conference, 2017, pp. 10821085 .

[5] R. Masykur, N. Nofrizal, and M. Syazali, "Pengembangan Media Pembelajaran Matematika dengan Macromedia Flash,” Al-Jabar J. Pendidik. Mat., vol. 8, no. 2, p. 177, Dec. 2017.

[6] H. Mustafidah, M. G. A. Imani, Sriyanto, and Suwarsito, "Development of Natural Science Learning Media in Primary School Using Flash Applications to Increase Student's Achievement," MATEC Web Conf., vol. 205, p. 00003, Sep. 2018.

[7] M. S. Sumantri, Strategi Pembelajaran Teori dan Praktik Ditingkat Pendidikan Dasar. Jakarta: Rajawali Pres, 2015.

[8] V. Iasha, M. S. Sumantri, S. Sarkadi, and R. Rachmadtullah, "Development Media Interactive Learning in Education Pancasila and Citizenship Education to Improve Tolerance of Students in Elementary School," in Advances in Social Science, Education and Humanities Research, 2018, vol. 251, no. Acec, pp. 311-314

[9] R. Rachmadtullah, Z. Ms, and M. S. Sumantri, "Development of computer - based interactive multimedia : study on learning in elementary education,” Int. J. Eng. Technol., vol. 7, no. 4, pp. 2035-2038, 2018.

[10] S. Anita, Media Pembelajaran. Surakarta: Yuma Pustaka, 2010.

[11] J. Tiede, S. Grafe, and R. Hobbs, "Pedagogical Media Competencies of Preservice Teachers in Germany and the United States: A Comparative Analysis of Theory and Practice," Peabody J. Educ., vol. 90, no. 4, pp. 533-545, Aug. 2015.

[12] A. Arsyad, Media Pembelajaran. Jakarta: Raja Grafindo Persada, 2014.

[13] S. E. Smaldino, D. L.Lowther, and J. D.Russell, Instructional Technology \& Media For Learning: Teknologi Pembelajaran dan Media untuk Belajar. Jakarta: Kencana Prenada Media, 2014.

[14] M. S. Sumantri and R. Rachmadtullah, "The effect of learning media and self regulation to elementary students' history learning outcome," Adv. Sci. Lett., vol. 22, no. 12, pp. 4104 $4108,2016$.

[15] A. Nurmariza, M. Ibrahim, and W. Widodo, "Pengembangan Bahan Ajar Berbasis Aktivitas Dengan Media CD Interaktif Pada Materi Indera Pendengaran Dan Sistem Sonar," J. Penelit. Pendidik. Sains, vol. 6, no. 1, pp. 1113-1122, 2016.

[16] Munir, H. Sutarno, and N. S. Aisyah, "The development of interactive multimedia based on auditory, intellectually, repetition in repetition algorithm learning to increase learning outcome,” J. Phys. Conf. Ser., vol. 1013, p. 012102, May 2018.

[17] J. A. Scaife, "Multimedia Motion II. CD-ROM and Teacher's Guide," Phys. Educ., vol. 35, no. 3, pp. 215-216, May 2000.

[18] W. W. Lee and D. L. Owens, Multimedia-based instructional design: computer-based training, web-based training, distance broadcast training, performance-based solutions. John Wiley \& Sons., 2004.

[19] F. R. A. Wulandari, N. R. Dewi, and I. Akhlis, "Pengembangan CD Interaktif Pembelajaran IPA Terpadu,” Unnes Sci. Educ. J., vol. 2, no. 2, p. 7, 2013.

[20] Hayumuti, H. Susilo, and S. Manahal, "Penggunaan Multimedia CD Interaktif dalam 
Peningkatan Aktivitas dan Hasil Belajar IPA Tema Selalu Berhemat Energi di Kelas IV SDN Klanderan Kediri,” J. Pendidik., vol. 1, pp. 1437-1441, 2016.

[21] T. Vaughan, Multimedia Making it work ;8th Edition. New York: McGraw-Hill, 2011.

[22] M. Haviz, "Computer-assisted Biology Learning Materials: Designing and Developing an Interactive CD on Spermatogenesis," IOP Conf. Ser. Mater. Sci. Eng., vol. 335, p. 012081, Apr. 2018.

[23] M. Tessmer, Planning and conducting formative evaluations. Routledge, 2013.

[24] H. A. Simatupang, "Pengembangan Media Pop-Up Pada Materi Organisasi Kehidupan Untuk meningkatkan motivasi dan Hasil Belajar Peserta Didik SMP Kelas VII,” Universitas Negeri Yogjakarta, 2016.

[25] R. Rachmadtullah, "Research Instrument:CD-Based Multimedia Interactive Thematic on Integrative Learning in Elementary School."

[26] R. Rachmadtullah, Nadiroh, Z. MS, and M. S. Sumantri, "Development of Interactive Learning Media on Civic Education Subjects in Elementary School Reza," in Advances in Social Science, Education and Humanities Research, 2018, vol. 251, pp. 293-296.

[27] Subyantoro and A. R. Fauzi, "Pengembangan CD Interaktif Menggali Informasi Dan Mendemonstrasikan Teks Permainan Tradisional Pembelajaran Tematik Bagi Peserta Didik Kelas III Sekolah Dasar," urnal Pendidik. Bhs. Dan Sastra Indones. , vol. 6, no. 1, pp. 17-26, 2018. 